\title{
Frege'de Yargıların Formel Mantıksal Analizi ve Düşünceler Üzerine
}

\section{On Thoughts and Formal Logical Analysis of Provision in Frege}

\author{
Diler Ezgi Tarhan ${ }^{1}$
}

'Dr., İstanbul, Türkiye

ORCID: D.E.T. 0000-0003-3208-9962

Sorumlu yazar/Corresponding author:

Diler Ezgi Tarhan,

İstanbul, Türkiye

E-mail/E-posta: dilertarhan@gmail.com

Başvuru/Submitted: 14.10.2019

Revizyon Talebi/Revision Requested:

12.12.2019

Son Revizyon/Last Revision Received:

17.12.2019

Kabul/Accepted: 26.12 .2019

\section{Atıf/Citation:}

Tarhan, Diler Ezgi. (2019). “Frege'de Yargıların Formel Mantıksal Analizi ve Düşünceler Üzerine" Felsefe Arkivi-Archives of Philosophy, 51: 235-247

https://doi.org/10.26650/arcp2019-5116

\section{ÖZET}

Frege, adların anlamları (Sinn) ile gönderimleri (Bedeutung) arasında yaptığı ayrımın bir türevini de yargılar üzerinde yapmış ve boşluklu fonksiyonlar olarak ele aldığı yargıları, 'doymamış' (ungesättigt) ifadeler; bir argümanla doldurularak tamamlanmış ifadeleri ise 'doymuş' (gesättigt) ifadeler olarak adlandırmıştır. Doymuş ifadeler, birinci ve ikinci düzey kavramlardan oluşmakta ve doğruluk değerine sahip anlamlı ifadeler olarak düşünülmektedir. Frege tüm bu formel analizi 'fonksiyon (Funktion) - argüman (Argument)' ve 'kavram - kaplam' ayrımı üzerinden temellendirmiş ve 'Begriffsschrift'te geliştirdiği formel mantık diliyle modern sembolik mantığın kurucusu olmuştur. Bu ayrıma dayanarak yargıların anlamını onların kendilerinde barındırdıkları 'düşünceler'; gönderimini ise işaret ettikleri doğruluk değerleri olarak saptayan filozof, düşünceleri hem yargıların bir doğruluk değeri alabilme koşulu olarak görmesi, hem de tümcelerin anlamına indirgemiş olması bakımından çelişkili bir kabulü benimsemiştir. Zira düşünceler, şayet gerçekten de Frege'nin zannettiği gibi tümcelerin anlamları olsaydı, o zaman anlamlı olmasına karşın doğruluk değerinden yoksun olan tümcelerden söz edilememesi gerekirdi. İşte bu sıkıntıyı aşmak üzere Frege'nin kuramındaki düşünce tanımını değiştirmeyi ve düşüncelerin tümcelerin anlamları değil, fonksiyon değerleri olarak görülmesini önermekteyiz. Zira bize göre düşünceler, tümcenin anlamı olmadığı gibi, gönderimi de değildir. Aksine düşünceler, tümcenin aldığı fonksiyon değeridir. Başka bir deyişle tümce bir fonksiyon değerine sahipse, doğru ya da yanlış olabilmekte; fonksiyon değerinden yoksunsa, anlamlı olabilmesine karşın doğru ya da yanlış olamamaktadır. Dolayısıyla bize göre düşünceler, ne tümcenin dildeki ifadesi, ne de tümcenin doğruluk değeridir; düşünceler, doğru ya da yanlış olabilen fonksiyon değerleridir.

Anahtar Kelimeler: Fonksiyon, argüman, kavram, kaplam, düşünce, yargı, doğruluk 


\begin{abstract}
Frege made a derivative of the distinction that he made between the meanings of senses (Sinn) and references (Bedeutung) on judgments, and named the judgments which he treats as hollow functions; 'Unsaturated' (ungesättigt) phrases and the phrases which completed an argument as, 'Saturated' (gesättigt) phrases. Saturated phrases consist of first and second level concepts and are considered to be meaningful expressions with an accurate value. Frege became the founder of modern symbolic logic with the language of formal logic he developed in 'Concept Writing', and based all this formal analysis on the distinction of 'function (Funktion) - argument (Argument)' and 'concept - coverage'. The philosopher, who makes sense of the judgments as their 'thoughts'; determines the logical value accuracy of the reference on the basis of this distinction, has adopted a contradictory acceptance in terms of both considering the judgments as a condition of being able to receive a truth value and reducing them to the senses of the sentences. Then, if the thoughts were indeed the sense of the sentences, as Frege thought, then it would not be possible to speak of sentences that were meaningful but lacked truthfulness. That is why, to overcome this distress, we propose to change the definition of thought in Frege's theory and to consider it as function values, not the sense of sentences. Likewise for us, thoughts are not the senses of the sentences, nor are they references. Contrariwise, thoughts are the function value of the sentences. To put it in a different way, if a sentence lacks function value, it can be meaningful but not true or false, and if the sentence has a function value, it can be true or false. Thus, for us, thoughts are neither the expression of the sentence in the language nor the logical value of the sentence; thoughts are function values that can be true or false.
\end{abstract}

Keywords: Function, argument, concept, coverage, thought, judgement, accuracy

Modern sembolik mantığın ve analitik felsefenin kurucusu sayılan Frege, 'Kavram Yazısı'nda (Begriffsschrift) geliştirdiği sembolik mantık dili sayesinde yargıların kavramsal bir analize tâbî tutulmasını mümkün kılmış ve yargıları özne ile yüklem arasında kopula ile kurulan bir bağıntı üzerinden ele alan klasik mantığın sınırlılığını aşmıştır. Frege'nin 'fonksiyon' (Funktion) 'argüman' (Argument) ayrımı üzerinden temellendirdiği bu analiz, boşluklu yapıdaki kavramların bir kaplama sahip olup olmamaları üzerinden doğruluk değerlerinin saptandığı yeni bir mantıksal analiz biçimidir. Bu analiz uyarınca özne ile yüklem arasındaki bağıntının çeşitli biçimlerde kurulabildiği ve önermelerin simgesel mantık dili üzerinden denetlenebildiği modern sembolik mantık geliştirilmiş olmaktadır. Frege'nin 'doymuş - doymamış' ifadeler ayrımı, yüklemsel doğadaki kavramların bir değerle doldurulup doldurulmama durumuna göre bir fonksiyon değerine gönderip göndermediğini belirlemekte, dolayısıyla da önermelerin doğruluk değeri alıp almama koşulları, sembolik bir fonksiyonel analize tâbi tutulmaktadır. Böylece doymuş ifadeler bir fonksiyon değerine göndererek o değer üzerinden doğruluk değeri almakta; doymamış ifadeler ise doğruluk değerinden yoksun kabul edilmektedir. Frege, kümeler kuramı üzerinden analiz ettiği bu kavram - kaplam ilişkisine dayalı analizi, kaplamı nesnelerden oluşan kümelerle kaplamı kavramlardan oluşan kümeler arasında da ayrı bir ayrıma tâbi tutmaktadır. Öyle ki kaplamı nesnelerden oluşan kavramlar, birinci düzey kavramlar (primäre Begriffe) olarak anılıp nesneleri nitelemelerine ve tümcede yüklem konumunda da kullanılabilmelerine karşın, kaplamı kavramlardan oluşan ikinci düzey kavramlar (sekundäre Begriffe) ise kavramları nitelemeleri bakımından tümcede yüklem pozisyonunda kullanılamamaktadır. Bu iki kavram türünden farklı olarak kaplamı boş küme olan kavramlar ise anlamlı olabilmelerine karşın herhangi bir gönderime sahip olmayan, dolayısıyla da doğruluk değerinden yoksun kabul edilen ifadelerdir. Görüldüğü üzere Frege’nin 'genel ad', 'genel terim' veya 'kavram terimi' şeklinde nitelediği 
kavramlar, kaplamı boş küme olmayan doymuş ifadeleri nitelemekte, sahte özel adlar ise kaplamı boş küme olan doymamış ifadelere işaret etmektedir.

'Begriffsschrift'te (birinci dereceden) kavramın doymamışlı̆̆ı, kavramın altına düşen nesne adının dolduracağı, en az bir boşluk içerme niteliği üzerinden izah edilmektedir. Bu boşluk ya da boşlukların her zaman doldurulması gerekmektedir. Bunlar bir özel ad (Eigenname) tarafından doldurulmaktan başka, sadece bir nesneye işaret etmekte olan bir gösterge tarafından da doldurulabilirler. ${ }^{1}$

Frege'ye göre her fonksiyon, argümanıyla eş-düzey bir ilişki içinde değildir. Kimi fonksiyonlar, argüman olarak kendi türevinin veya integralinin alındığ 1 " $F\left(f_{(1)}\right.$ )" gibi ikinci düzey fonksiyonlardır. ${ }^{2}$ Daha doğru bir deyişle ikinci düzey kavramlar, birinci düzey kavramlara yüklemlenirken birinci düzey kavramlar ise nesnelere yüklemlenmektedir.

Nesneler arasındaki aynılık ilişkisini 'birinci dereceden ilişki’ olarak adlandırdığım yerde, kavramlar-arası ilişki ise benim tarafımdan 'ikinci dereceden ilişki' olarak adlandırılmaktadır. 'B' nesnesinin altına düştüğü her kavramın alına 'a' nesnesinin de düşüyor olması ve tam tersi durumda biz, (bu iki nesne arasında eksiksiz bir örtüşme olması anlamında) 'a' nesnesinin 'b' nesnesiyle aynı olduğunu söyleyebiliriz. Kavram ile nesne rollerinin yer değiştirmesi halinde aynı durumu kavramlar için de elde etmekteyiz. Öyleyse yukarıda düşünülmüş olan ilişkinin, ' $\Phi$ ' kavramının altına düşen her nesnenin ' $\mathrm{X}$ ' kavramının da altına düşmesi ve tam tersi durumunda ' $\Phi$ ' ve 'X' kavramları arasında da söz konusu olduğunu söyleyebiliriz. ${ }^{3}$

Görüldüğü üzere Frege kavramların doğruluk değerlerini belirlerken onların kaplamlarından yola çıkmış ve kaplamları arasında eşleme bağıntısı kurulabilen kavramların 'eş-değer' olduklarını ileri sürmüştür. Bu kaplamlar arası 'eş-değerlik' bağıntısı, ikinci düzey kavramlarda bizi kaplamlar arası bir 'eş-sayılılık' ilişkisine götürmekte ve bu 'eş-sayılı' kümelerin kümesi ise bize sayı nesnesinin kümesini vermektedir. Dolayısıyla yukarıdaki alıntıdan hareketle düşündünüldüğünde ' $\Phi$ ' kavramı altına düşen her unsur, ' $\mathrm{X}$ ' kavramı altına düşen bir unsura karşılık düşmekte ve bu iki kavramın kaplamları arasında hiçbir unsur boşta kalmayacak şekilde bir eşleme bağıntısı kurulabilmekteyse bu durum, bahsi geçen ' $\Phi$ ' ve 'X' kavramlarının kaplamları arasında bir eşdeğerlik olduğunu göstermektedir. Tam da bu nedenle ‘ $\Phi$ ' kavramı, “'X' kavramıla eşsayılı olan kavram” olarak ve aynı şekilde 'X' kavramı da “' $\Phi$ ' kavramıyla eşsayılı olan kavram” olarak tanımlanabilmektedir. Bu noktada mühim olan şey, "kavram - kaplam” analizinin, içerik ve içeriğin dile getirilişi arasındaki ayrımın muhafaza edildiği bir zeminde, formel bir değerlendirmeye tâbî tutulmasıdır ki Frege

1 Frege, Gottlob, “Ausführungen Über Sinn und Bedeutung” (1892-1895), s.29, şurada: Gottfried, Gabriel, "Schriften zur Logik und Sprachphilosophie”, Felix Meiner Verlag, Hamburg, 1969, ss.25-34.

2 Frege, Gottlob, “Über Funktion und Begriff”, şurada: Frege, Gottlob, “Funktion, Begriff, Bedeutung. Fünf Logische Studien”, Ed: Patzig, Günther, Kleine Vandenhoeck, 5.Baskı, 1980, Göttingen, ss.18-39 içinde, s.38.

3 Frege, Gottlob, “Ausführungen Über Sinn und Bedeutung” (1892-1895), şurada: Gottfried, Gabriel, "Schriften zur Logik und Sprachphilosophie”, Felix Meiner Verlag, Hamburg, 1969, ss.25-34 içinde ss.28-29. 
sözkonusu formel analizi, geliştirdiği kavram yazısı sayesinde "fonksiyon - argüman” bileşenleri üzerinden ortaya koymuş ve bu formel analizin bir görüsellikle gölgelenmesine izin vermemiştir.

Frege, 9 Ocak 1891'de "Jena Tip ve Doğa Bilimleri Topluluğu” (Jenaischen Gesellschaft für Medizin und Naturwissenchaft) sempozyumunda sunduğu bildiriden hareketle yayınlanan 'Fonksiyon ve Kavram Üzerine' (Über Funktion und Begriff) 4 adlı metninde ünlü 'fonksiyon - argüman' ayrımını, 'anlam - gönderim' ayrımı üzerinden ele almış ve yargıların formel analizini ortaya koymuştur. Frege, aritmetik eşitlikler arasındaki analitik ve sentetik ayrımın kökeninde yattığını ileri sürdüğü 'anlam - gönderim' ayrımını önce yargılar üzerinde uygulamış, akabinde özel adlar açısından ele almıştır, zira Frege'ye göre kavramlara, yargılardan hareketle varılmaktadır. Dolayısıyla Frege kavramlardan yargılara değil, yargılardan kavramlara geçmiştir. Önce dilin mantıksal analizini mümkün kılacak nesnel bir formülasyon geliştirerek yargıları 'fonksiyon - argüman' ayrımı üzerinden çözümleyen filozof, daha sonra bu 'kavram (Begriff) nesne (Gegenstand)' ayrımını 'anlam - gönderim' ayrımıyla beraber ele almıştır.

Frege’ye göre yargılar, yüklemsel doğaya sahiptirler. Dolayısıyla yargıların kendisine yüklemlendiği ifadelerin türü, yargıdan hareketle belirlenmekte; her yargı, gönderimde bulunduğu fonksiyon değeri üzerinden bir doğruluk değerine sahip olmaktadır. Öte yandan yarg1, gönderimsiz bir sahte özel ad içerdiğinde hiçbir doğruluk değerine sahip olmazken ancak birinci veya ikinci düzey kavramlar içermesi hâlinde doğru veya yanlış değeri alabilmektedir. Frege, kaplamı nesnelerden oluşan kavramlara 'birinci düzey kavram', kaplamı kavramlardan oluşan kavramlara ise ‘ikinci düzey kavram’ adını vermiştir. Kaplamı ister nesnelerden ister kavramlardan oluşsun, bu kaplamın kendisi Frege'de bir nesne olarak ele alınmaktadır. Dolayısıyla fonksiyon biçimindeki yargılar birer kavram olarak düşünülürken kaplamı oluşturan değerler alanı (Wertverlauf) ise bir nesne olarak düşünülmektedir. İşte bu nokta, Frege'de eleştiri konusu olan noktalardan biridir. Zira ikinci düzey bir kavramın kaplamının, kavramlardan oluşmuş olmasına karşın bu değerler alanının nasıl olup da bir nesne olarak düşünüldüğü konusunda Frege herhangi bir açıklamada bulunmamıştır.

Fonksiyonun boşluğunu dolduran argümanlar, fonksiyonun göndereceği değeri belirlemekte ve ifadenin doğruluk değeri, fonksiyonun gönderdiği bu değer üzerinden belirlenmektedir. Frege, fonksiyon değerinin de o değer üzerinden ifadenin aldığ 1 doğruluk değerinin de yine kavramın kaplamı olan değerler kümesi gibi bir mantıksal nesneye karşılık düştüğünü savunmaktadır. Yani yüklemsel ve boşluklu yapıdaki fonksiyonlar, argümanla doldurulmayı talep eden kavramlardır. Onların boşluğunu dolduran argümanlar ise nesne olabileceği gibi kavram da olabilmektedir. Ancak ister nesne, ister kavramla doldurulsun, her boşluklu kavramın altına düşen değerler alanı, onun kaplamı olarak bir nesne statüsünde görülmektedir. Bu kaplam sayesinde fonksiyonun gönderdiği değer belirlenmekte ve o değerin ifadeyle uygunluğuna/uygunsuzluğuna göre de tümcenin doğruluk değeri saptanmaktadır. Bizim bu makaleyle ortaya koymayı amaçladığımız özgün yorum, işte tam da bu noktada belirmektedir. Çünkü bize göre Frege'nin düşüncelerle kast ettiği, tümcenin anlamı olmaktan ziyade gönderdiği bu fonksiyon değeri olmalıdır. Aksi halde 
Frege, düşüncelerin tümcelerin anlamı olduğunu söylemekle derin bir yanılgıya düşmektedir, çünkü Frege açısından düşünceler, aynı zamanda tümcelerin doğru ya da yanlış olabilme koşuludur. İşte tam da bu durum Frege'nin kendisiyle çelişmesine neden olmaktadır, çünkü hem anlamlı hem de doğruluk değerine sahip tümcelerde, düşüncelerin tümcenin anlamı olarak görülmesi bir çelişki teşkil etmezken, anlamlı olmasına karşın doğruluk değerinden yoksun olan tümcelerde ifadenin nasıl olup da gönderimsiz olmasına karşın bir düşünce içerebildiği sorusu yanıtsız kalmaktadır. Şayet düşünceler gerçekten de Frege'nin dediği gibi tümcelerin anlamı ise o zaman anlamlı olan her tümce düşünce de içereceğinden, anlamlı olmasına karşın doğruluk değerinden yoksun tümcelerden söz edilememesi gerekirdi, zira Frege düşüncelerin aynı zamanda tümcelerdeki doğruluk değerinin taşıyıcısı olduğunu ileri sürmektedir. İşte bu çelişkinin aşılması için biz Frege'nin düşüncelerle kast ettiğinin tümcenin anlamı olmaktan ziyade fonksiyon değeri olması gerektiği kanaatine vardık. Ancak bu koşulla Frege'nin düşünce tanımı, hiçbir çelişkiye mahal vermeyecek şekilde Frege'nin kuramında yerli yerine oturtulabilir. Nitekim düşünceler, tümcelerin gönderimde bulunduğu doğruluk değerleri olarak değil de tümcelerin adlığı fonksiyon değerleri olarak düşünüldügünnde bu değerler, hem her anlamlı tümcede bulunmamak bakımından anlamlı olmasına karşın doğruluk değerinden yoksun olan önermelerin olanağını kurtarmakta, hem de tümcelerin doğruluk değeri alma koşulu olarak görülmeleri herhangi bir sıkıntıya yol açmamaktadır.

Frege, hem bir düşünceye hem de bir doğruluk değerine sahip olan ifadeleri 'fonksiyon argüman’ ayrımı üzerinden formel bir analiz zeminine taşımıştır. Aritmetik yasaların mantık yasalarından çıkarılabileceğini düşündüğü için aritmetik yargıları mantıksal simgeler üzerinden ifade eden filozof, bu sembolik dil yardımıla yargıların formel mantıksal bir analizini gerçekleştirmiştir. Öyle ki " $f_{\left(x^{\prime} \text { in baskenti) }\right.}$ " ifadesi, 'x' argümanı yerine "Alman İmparatorluğu” getirildiğinde "Alman İmparatorluğu'nun başkenti" ${ }^{5}$ ifadesine dönüşmekte ve "Berlin" değeri için 'doğru', Berlin dışındaki herhangi bir değer (Londra, Barselona, Moskova vs.) için 'yanlış' kabul edilmektedir. Demek ki " $f_{(x \text { 'xin baskenti) }}$ " fonksiyonu, bir ' $\mathrm{x}$ ' argümanıyla doldurulunca doymuş bir ifadeye dönüşerek bir doğruluk değerine sahip olmakta, aksi halde doymamış bir ifade olduğu için anlamlı olmasına karşın 'doğruluk değerinden yoksun' kabul edilmektedir. İşte tümcedeki düşünce, " $f_{(x)}$ ” fonksiyonuyla ifade edilen değil, kendisine gönderilen, fakat doğruluk değerinin kendisi de olmayan fonksiyon değeri olarak " $y$ " dir. Yani " $f_{(x)} \rightarrow y$ " ifadesinde " $f_{(x)}$ " ifadesi, bir " $x$ " argümanıyla doldurulma durumunda "y" gibi bir değere göndermekte ve bu değer, fonksiyonun doğru ya da yanlış olabilmesine imkân tanıyan düşünceyi karşılamaktadır. Yani düşünce, ne tümcenin anlamı, ne de tümcenin doğruluk değeri olarak düşünülmelidir.

Frege’ye göre tümce içinde yer alan özel adların bir gönderime (Bedeutung) sahip olması hâlinde tümce bir düşünce içermekte ve bu düşünce üzerinden bir doğruluk değerine göndermektedir. Örneğin “ $x$ ’in karekökü” ifadesi ‘ 4 ’ argümanı için ' +2 ' veya ' -2 ' sonucuna; ' 36 ' değeri için ise ' 6 ' sonucuna götürmektedir. Şayet “' in karekökü” ifadesinin ' 4 ' değeri için ' +2 ' veya ' -2 'ye değil de ' 1 ' sonucuna

5 Frege, "Über Funktion und Begriff”, s.29. 
gönderdiğini söylersek bu fonksiyon yine bir düşünce içermiş olur, ancak içerdiği düşüncenin doğruluk değeri 'yanlış' olur. Demek ki yargının doğru ya da yanlış olabilme koşulu, bir düşünce ifade etmesinden geçmektedir. ${ }^{6}$

$\mathrm{F}_{(\mathrm{x})}$ gibi bir fonksiyon, bir ' $\mathrm{x}$ ' değeriyle doldurulmaması halinde bir anlam ifade ediyor olmasına karşın bu anlam, doğrulabilir bir düşünce içermemektedir, çünkü düşünce, tümcenin anlamından ziyade, doğruluk taşıyıcısı olan fonksiyon değeridir. Doğruluk değerinden yoksun ifadelerde " $f_{(\mathrm{x})}$ ” ifadesi bir " $x$ ” değeriyle doldurulamadığı için “ $y$ ” gibi bir değere gönderememekte, dolayısıyla ifade anlamlı olmasına karşın bir fonksiyon değerine göndermediğinden hiçbir düşünce barındırmamakta, bu nedenle doğru ya da yanlış olamamaktadır.

Daha açık ifade edecek olursak: "f(x'in başkenti)" gibi boşluklu bir fonksiyon, alacağ 1 x değerine göre farklı bir gönderime sahip olmakta ve bu gönderim üzerinden doğruluk değeri teşhis edilmektedir. Örneğin " $x$ ” değişkeni "İngiltere” argümanıyla doldurulduğunda, "f(İngiltere’nin başkenti)" ifadesi "Londra” değerine göndermesi halinde doğru; "Berlin” veya başka bir şehir adına göndermesi durumunda ise yanlış değeri almaktadır. Demek ki fonksiyonların doğruluk değerleri, onların boşluklarını dolduran argümandan ziyade o argümanla doldurulmuş fonksiyonun, aldığı fonksiyon değeriyle uygunluğuna / uygunsuzluğuna göre belirlenmektedir. Dolayısıyla Frege'de doğruluğun nesnesine uygunluğundan ziyade bağıntı merkezli bir upuygunluktan veya upuygunsuzluktan söz edilebilir. İşte burada kaplamı boş küme olmayan, yani bir doymuş ifade, kendisini dolduran argüman değerine göre bir fonksiyon değerine göndermekte ve o fonksiyon değeri üzerinden de bir doğruluk değerine sahip olmaktadır. Bize göre işte Frege'nin "düşünce" dediği mantıksal nesneler, olsa olsa bu fonksiyon değerlerinin kendisidir. Nitekim "f(İngiltere'nin başkenti)" ifadesi, "İngiltere” argümanıyla doldurulduğunda, gönderdiği fonksiyon değerinin "Londra" olması durumunda doğru, "Berlin" veya bir başka şehir olması durumunda yanlış değerini almaktadır. Demek ki "Londra” değeri, "f(İngiltere’nin başkenti)” ifadesi için bu ifadenin hangi doğruluk değerini alacağının kendisine göre belirlendiği düşüncedir. Yani bize göre Frege, düşünce içeren her tümcenin bir doğruluk değeri almasına karşın, düşünceden yoksun tümcelerin de anlamlı olabilme olanağını yalanlamayan tutarlı bir açıklamayı ancak bu şekilde verebilirdi.

Öte yandan Frege, fonksiyonların doğruluğunun hangi yasalılığa göre saptandığı meselesini araştırırken gösterge ile gösterilen, anlam ile gönderim, biçim ile içerik, kavram ile nesne arasında belirgin bir ayrım yapılması gerektiğine inanmaktadır. Matematiksel fonksiyonların dildeki ifadesini 'anlam'; gönderimde bulundukları nesneyi ise 'gönderim' olarak kabul eden filozof, bu ayrım sayesinde kavramın kaplamını, doğruluk değerinden ayırmış; aritmetik eşitliklerde farklı sayısal ifade ve işlemler arasında kurulan özdeşlik bağıntısını semantik bir zemine oturtmuş ve “ $2.2^{3}+2=18$ ” gibi aritmetik ifadelerde eşitliğin sağ tarafındaki göstergelerin, sol tarafındaki göstergelerle nasıl olup da aynı gönderime sahip olabildiğini açıklamıştır.”7 Frege açısından sayal sayıları nesnesinden ayırmak, yani sayal sayının göstergesiyle nesnesi arasında bir ayrım yapmak şarttır. Çünkü ancak bu sayede "2”, “1 + 1”, “3 - 1”, “6:3” gibi ifadelerin farklı sayısal ifadeler

6 Tarhan, “Husserl ve Frege'de Anlam Sorunu”, s.198.

7 Frege, “Über Funktion und Begriff”, s.19. 
üzerinden aynı gönderime sahip olmaları durumu açıklanabilir. ${ }^{8}$ Başka bir deyişle sayısal işlemler, dilde farklı gösterge ve bağıntılardan hareketle ifade edilebilir olmalarına rağmen, ancak anlam ile gönderim arasında yapılan ayrım sayesinde eş-gönderimli kabul edilebilmektedir. Söz konusu ayrım olmaksızın " $\mathrm{x}^{2}=4$ ” eşitliğindeki ' $\mathrm{x}$ ' değişkenin nasıl olup da aynı anda hem ' +2 'ye hem de '-2'ye gönderebildiği açıklanamaz olmakla birlikte, ayrıca ' $x$ ' ' ifadesinin nasıl olup da '4' rakamıyla eşit kabul edilebildiği de açıklanamaz. ${ }^{9}$ Dolayısıyla anlam ile gönderim arasında yapılan ayrım, dilde farklı gösterge ve ifadeler üzerinden aynı şeyin kast edilmesini mümkün kılmaktadır.

Frege'ye göre boşluklu fonksiyon, bir argüman ile doldurulduğunda 'doymuş' hâle gelmekte ve kaplamı üzerinden bir gönderime sahip olmakta; doymamış ifadeler ise altına hiçbir nesne ya da kavramın düşmediği eksik ifadeler olarak ne doğru ne de yanlış kabul edilmektedir.

Öyle ki kavram, bir argümanın fonksiyonudur; fonksiyonun değeri ise daima kavramın doğruluk değeridir. İlk etapta verili durumlarda, argümanın kendisi nesneydi ve biz konuyu bu ilk verili durumlarla sınırlandırmak niyetindeyiz. Kavramlarda ise artık değerin her daim 'doğruluk değeri' olduğu özel bir durumla karşı karşıyayız. Yani biz bir kavram adını, bir özel adla tamamladığımızda, anlamı düşünce (Gedanke) olan bir tümce elde etmekteyiz ve bu tümce, gönderim olarak bir doğruluk değeri (Wahrheitswert) içermektedir. Biz bu gönderimi, doğru olana ait gönderim olarak (doğru olan olarak) kabul etmekle, bu gönderimin, altına argüman olarak nesne düşen bir kavram olduğunu ifade etmiş olmaktayız. Fonksiyonda doymamışlı olarak adlandırılan bu durumu, kavramlar söz konusu olduğunda, 'kavramın yüklemsel doğası' şeklinde adlandırabiliriz. ${ }^{10}$

Frege, "fonksiyonun bir argümanla tamamlanması sonucunda elde edilen sonuca, fonksiyonun o argüman için aldığı 'fonksiyonun değeri' adını vermektedir." 11 Frege, fonksiyon boşluğunu dolduran argümanın görüsel nitelikte olmasını geometri için mümkün görmekle birlikte aritmetikte reddetmektedir. Zira Frege'ye göre aritmetik önermeler Kant'ın savunduğu gibi sentetik apriori değil, analitik önermelerdir. Ayrıca Frege’ye göre mantık ve aritmetik alanında görü temelli bir bilginin elde edilmesi zaten olanaksızdır, çünkü aritmetik nesneler, mantıksal nesneler olmaları bakımından ancak dilde onların yerini tutan sözcüklerin tümce bağlamındaki işlevlerinin analiz edilmesi sayesinde yakalanabilirler. Dolayısıyla bu nesnelerin düşünülme ve yakalanma süreci, görü temelli bir deneyime indirgenemeyecek kadar kavramsaldır. Bu nedenle Frege, görüsel deneyimi yalnızca geometri açısından benimsemiş ve bu görü temelli argümanı "apsisin sayısal değeri" 12 olarak nitelemiştir. Keza bu gibi bir sayısal değer üzerinden fonksiyonun gönderdiği fonksiyon değeri ise "bir nokta ordinatının sayısal değeri”"13 olarak adlandırılmaktadır. Yani analitik geometride karşılaşılan fonksiyonlar, mantıktaki yüklemsel fonksiyonlardan ziyade

8 A.g.e., s.20.

9 A.g.e., s.20-21.

10 Frege, “Ausführungen Über Sinn und Bedeutung”(1892-1895), s.27.

11 Frege, "Über Funktion und Begriff”, s.22.

12 A.g.e., s.23.

13 A.g.e., s.23. 
eğrisel fonksiyonlardır ve eğriler üzerinden görüsel biçimde deneyimlenen bu noktalar kümesi, her bir noktasının farklı bir fonksiyon değerine gönderdiği çoklu bir yönelimi ifade etmektedir.

Frege, aynı fonksiyonun kendisini tamamlayan argümana göre farklı değerler alabilmesini mümkün kılan boşluklu yapıyı ise 'mantıksal form' olarak adlandırmaktadır. Örneğin " $2 \cdot \mathrm{x}^{3}+\mathrm{x}^{3}$ ” gibi bir ifade, alacağı ' $\mathrm{x}$ ' değerine göre farklı bir fonksiyon değerine göndermekte ve bu değer, fonksiyonun doğruluk değerinin ne olacağını belirlemektedir. Nitekim bu ifade ' $x$ ' yerine ' 1 ' değeri geldiğinde “ 3 ” sonucuna göndermesi halinde 'doğru', başka bir değere göndermesi halinde 'yanlış' kabul edilmektedir. Aslında Frege, fonksiyon değerinin değişken yapıda olduğu mantıksal formu, fonksiyon değerinden bağımsız olarak şöyle ifade etmektedir: " $2 \cdot \mathrm{x}^{3}+\mathrm{x}^{3}$ " ifadesinin mantıksal formu, "2.(... $)^{3}+(\ldots)$ " ifadesidir. ${ }^{14}$ Görüldügü gibi Frege’de fonksiyonun mantıksal zorunluluğu, onun tamamlanmayı talep eden boşluklu yapısından kaynaklanır. Yani mantıksal değişmez, fonksiyonun bir argümanla doldurulma olanağıdır. İşte Frege'nin düşünceleri, tümcenin anlamı olarak görmekle düştüğü hata, aslında Frege'nin düşüncelerle kast ettiğinin bu mantıksal olanak olamayacağının anlaşılmasıyla daha da net bir biçimde ortaya çıkmaktadır. Zira fonksiyonun dildeki formu olarak bu mantıksal olanak, tümcenin anlamından başkası değildir ve bu anlam, tümcenin doğruluk değerini değil, gönderdiği fonksiyon değerini belirlemek bakımından düşünceyle bir tutulamaz. Zira " $2 \cdot \mathrm{x}^{3}+\mathrm{x}^{3}$ " ifadesinin doğruluk değeri, “2.(... $)^{3}+(\ldots)$ ” ifadesi üzerinden değil, bu ifadenin doymuş halinin gönderdiği fonksiyon değeri üzerinden belirlenmektedir. " $2 \cdot \mathrm{x}^{3}+\mathrm{x}^{3}$ ” ifadesinin gönderdiği doğruluk değeri " $\mathrm{x}=1$ ” argümanı için “ 3 ” değerine gönderiyorsa bu ifade doğru, başka bir değere gönderiyorsa bu ifade yanlış değeri almaktadır. Demek ki ifadenin doğru mu yanlış mı olduğu ifadenin mantıksal formuna (anlamına) göre değil, gönderdiği fonksiyon değerine göre belirlenmektedir ki biz de zaten düşüncelerin, tümcelerin anlamı değil, gönderdiği fonksiyon değeri olarak görülmesi gerektiğini bu nedenle savunuyoruz.

Frege, aynen birçok sayının yerini tutabilen belirsiz değişkenleri harflerle imlediği gibi aynı şekilde kavramın genelliğini de harflerle ifade etmektedir. Yüklemlerin 'fonksiyon - argüman' ayrımı üzerinden " $\mathrm{f}(\mathrm{x}) \rightarrow \mathrm{y}$ ” şeklinde ele alınıp incelenmesinde olduğu gibi tüm kompleks ifadelerin sayılar, harfler ve bağıntılar üzerinden formüle edilmesini mümkün kılan kavram yazısı ile Frege, yargıların toplam, çarpım, büyüklük, küçüklük, özdeşlik vb. göstergeler üzerinden analiz edilebildiği sembolik bir mantık dili geliştirmiştir. Frege’ye göre bu mantık dili, özdeşlik bağıntısını fonksiyonlar arasında değil, fonksiyonların doğruluk değerleri arasında kuran ve kavramlar-arası ilişkileri kaplamlar-arası ilişkiler üzerinden ele alan yeni bir dildir. Bu dil sayesinde “ $(2=4)=(2>1)$ ” gibi ifadelerin doğruluğu gerekçelendirebilmekte ve " $2=4$ ” ifadesi ile " $2>1$ ” ifadesi arasında bu iki ifadenin gönderimleri üzerinden bir özdeşlik bağıntısı kurulabilmektedir. Yani Frege, ifadelerin anlamı ve içeriğinden ziyade gönderimi ve doğruluk değeriyle ilgilenmektedir. Bu nedenle her iki ifadenin de beraberce 'doğru' veya beraberce 'yanlış' değerine göndermesi durumunda bu ifadeler arasında sorunsuz bir özdeşlik ilişkisi kurulabilmekte; fakat aynı doğruluk değerine göndermeyen ifadeler arasında benzer bir özdeşlik ilişkisi kurulamamaktadır.

14 A.g.e., s.21. 
Aynı şekilde " $\left(2^{2}=4\right)=(2>1)$ ” 15 ifadesinde özdeşlik, eşitliğin iki tarafındaki ifadeler arasında değil, bu ifadelerin gönderdiği doğruluk değerleri arasındaki bir eşitliğe işaret etmektedir.Yani her ikisi de beraberce aynı doğruluk değerini alan ifadeler arasındaki eş-gönderimlilik, kaplamlar-arası bir eşdeğerlik üzerinden saptanmaktadır. Fakat burada, gönderimler-arası özdeşliğin düşüncelerarası özdeşliğe işaret etmediğinin altını çizmek gerekir. Yani Frege’ye göre gönderimler arası aynılıktan, düşünceler arası aynılığın çıkarılması mümkün değildir. ${ }^{16}$ Nitekim farklı düşünceler içeren ifadeler, aynı doğruluk değerine sahip olabilmektedir. Başka bir deyişle düşünce, tümcenin doğruluk değeri değil, doğruluk değeri alabilme koşulu olduğundan doğruluk değerleri arasındaki özdeşlik ilişkisi, düşünceler arası aynılık ilişkisine indirgenememektedir.

Frege'ye göre eş-gönderimli ifadelerin birbirleriyle yer değiştirmeleri durumunda tümcenin anlamı değişse de gönderimi aynı kalmaktadır. Frege’nin kendi ifadesiyle söyleyecek olursak: "Bir kelimeyi onunla aynı gönderime işaret eden, fakat başka anlama sahip farklı bir kelimeyle değiştirdiğimizde, tümcenin genel gönderiminde hiçbir değişiklik olmamaktadır." ${ }^{17}$ Nitekim "Akşam Yıldızı, kendi etrafındaki dönme süresi, dünyadan daha kısa olan gezegendir"18 ifadesiyle "Sabah Yıldızı, kendi etrafındaki dönme süresi, dünyadan daha kısa olan gezegendir" ${ }^{19}$ ifadeleri arasındaki tek fark "Akşam Yıldız”" (Abendstern) ifadesiyle "Sabah Yıldız” (Morgenstern) ifadelerinin anlamları arasındadır. Oysa her iki tümcede de bu iki sözcükle aynı yıldıza (Venüs) işaret edilmekte olduğundan, her iki tümcenin de gönderdiği doğruluk değeri aynıdır.

Aynı kaplama sahip kavram sözcüklerinin birbirleriyle yer değiştirmeleri, doğruluk değerinde hiçbir değişikliğe yol açmamakta ve çıkarımlar, mantık yasalarıyla bağlantılı olarak yalnızca kavramların farklı kaplamlara sahip olmaları durumunda birbirlerinden ayrılmaktadır. Temel mantıksal ilişki, tüm kavramlar arası ilişkilerin kendisine dayandırıldığı; nesnelerin bir kavram altına düşme ilişkisidir. ${ }^{20}$

Dolayısıyla yargıların anlamının onların dildeki fonksiyonel ifadesine, gönderiminin ise onların doğruluk değerlerine karşılık geldiğini savunan Frege, yargıların doğruluk değeri alabilme koşulunu kaplamının boş küme olmamasına ve bir 'düşünce' içermesine bağlı görmüştür. Fakat Frege düşünceyi, doğrudan tümcenin anlamı olarak görmekle yukarıda da ifade ettiğimiz üzere hataya düşmüştür. Nitekim düşünce doğrudan tümcenin anlamı olarak düşünüldüğünde, anlamlı olmasına karşın bir doğruluk değerinden yoksun olan tümceler açılanamaz hâle gelmektedir. Oysa düşünce, Frege'nin iddia ettiği gibi tümcenin anlamı değil, fonksiyon değeridir. Aksi halde anlamlı olmasına karşın düşünceden yoksun ifadelerden söz edilemeyeceği gibi doğruluk değerinden yoksun her ifade de anlamsız kabul edilir ki bu da Frege'nin kendisiyle çelişmesi demektir. Nitekim Frege'de sahte özel ad içeren tümceler, doğruluk değeri almamasına karşın anlamlı kabul edilmekte ve düşünce içermedikleri savunulmaktadır. Şayet düşünce, anlama

15 A.g.e., s.26.

16 A.g.e., s.26.

17 Frege, Gottlob, “Über Sinn und Bedeutung”, s.47.

18 Frege, "Über Funktion und Begriff”, s.26.

19 A.g.e., s.27.

20 Frege, “Ausführungen Über Sinn und Bedeutung”(1892-1895), s.25. 
indirgenirse bu tümcelerin nasıl olup da anlam içermelerine karşın düşünce içermedikleri ise açıklanamaz hâle gelmektedir. Frege, düşünceyi, düşüncenin dile getirilişinden ayırmak noktasındaki hassasiyetini göz ardı ederek düşüncenin, tümcenin anlamı olduğunu söylemesi bakımından derin bir yanılgıya düşmüştür.

"Burada dikkat edilmesi gereken nokta, bir düşüncenin dile getirilişii olan tümcenin her zaman düşüncenin kendisinden farklı olmasıdır. Düşünce, tümce kılığına bürünmüş olarak ortaya çıkmaktadır." ${ }^{21}$

İşte bize göre, - yukarıda da zaten ifade etmiş olduğumuz üzere - , Frege, düşüncenin tümcenin anlamı değil de fonksiyon değeri olduğunu söyleseydi, bahsi geçen sıkıntıların hiçbiri doğmayacaktı, çünkü gerçekten de o zaman sahte özel ad içeren tümcelerin düşünce içermedikleri yönündeki Fregeci sav havada kalmayacaktı. Düşünce, fonksiyon değeri olarak düşünüldügünde, sahte özel ad içeren tümcelerin hiçbir gönderimi bulunmaması nedeniyle düşünce içermemeleri de bir çelişki barındırmamaktadır. Zira "Fransa’nın şimdiki kralı keldir” gibi bir tümce, "Fransa'nın şimdiki kralı" ifadesinin zaten hiçbir fonksiyon değerine göndermemesi nedeniyle düşünce içermediğinin söylenmesi de sıkıntı doğurmamaktadır. Yani bize göre Frege, düşünceleri, fonksiyon değeri olarak görmekle hem sahte özel ad içeren tümcelerin anlamlı olmasına karşın doğruluk değerinden yoksun olmaları durumunu açıklayan bir "düşünce” tanımı vermiş olacaktı, hem de - kendisiyle çelişmek pahasına - tümcelerin doğruluk değeri alma koşulunu anlamlı olmalarına indirgeme hatasına düşmemiş olacaktı. Nitekim Frege, tümcenin doğruluk değerini, "tümceyi oluşturan unsurların Bedeutung'larının bir fonksiyonu olarak görmekte" ${ }^{22}$, bu nedenle de tümcede gönderimsiz bir ifade (sahte özel ad) bulunduğunda tümcenin gönderimden yoksun olacağını ileri sürmekte; fakat bu tümcelerin doğru ya da yanlış olamamalarına karşın anlamlı kabul edilebileceklerini savunmaktadır. Oysa düşünceler, tümcenin anlamı olarak görülmeleri durumunda hiçbir doğruluk değeri almayan gönderimsiz ifadelerin bir düşünce içermemelerine karşın nasıl olup da anlamlı kabul edilebildiği açıklanamamaktadır. Bu nedenle söz konusu çelişkinin aşılabilmesi için Frege'nin, "Düşünce" (Der Gedanke)23 adlı yazısında ifade ettiği "Düşünceler tümcelerin anlamlarıdır”24 şeklindeki beyanın, düşüncelerin tümcelerin anlamıyla özdeş olduğu yönünde değil, düşüncelerin tümcelerin gönderdiği fonksiyon değerlerinin bir fonksiyonu olduğu şeklinde yorumlanması gerekmektedir. Çünkü her anlamlı tümce, doğrulanabilir ve sınanabilir bir düşünce içermemektedir. Fakat düşünce içeren her tümce doğrulanabilir bir anlam bildirmektedir. Buradaki ayrım, tümcede ifade edilen anlam içeriğinin türüyle ilgilidir. Düşünce içeren bir anlam söz konusu olduğunda tümcede ifade edilen anlam,

21 Güven, Özgüç, “Kant, Bolzano ve Frege’de Yargıların Temellendirilmesi ve Apriorilik Sorunu”, İstanbul Üniversitesi Sosyal Bilimler Enstitüsü Felsefe Anabilim Dalı Doktora Tezi, İstanbul, 2012.s.189.

22 Tümcenin doğruluk değerinin, tümceyi oluşturan unsurların doğruluk değerleri üzerinden belirlenmesini şart koşan prensip, 'Frege Prensibi', 'Funktionalitätsprinzip’'veya 'Kompositionalitätsprinzipp' olarak anılmaktadır. Tarhan, Diler Ezgi, “Husserl ve Frege'de Anlam Sorunu”, İstanbul Üniversitesi Sosyal Bilimler Enstitüsü Felsefe Anabilim Dalı Doktora Tezi, 2019, 186 no.lu dipnot, s.167.

23 Frege, Gottlob, “Der Gedanke”, şurada: Frege, Gottlob, “Beiträge zur Philosophie des deutschen Idealismus”, 1918-1919, ss.58-77.

24 A.g.e. s.61. 
doğrulanabilir bir anlam olmakta; aksi halde tümcede ifade edilen anlam, doğrulanamaz bir malûmat içermektedir.

Frege, bir tümcenin düşünce içermesine rağmen bir 'Bedeutung’a göndermemesini olanaksız bulmaktadır. Zira tümcenin anlamlı olması da bir düşünce ifade etmek zorunda olduğu anlamına gelmemektedir. Bu nedenle de bir tümce Sinn’i olsa bile düşünceden yoksun olabilmekte; düşünce ifade etmeme durumunda ise peşinen gönderimsiz kabul edilmektedir. Dolayısıyla sahte özel ad içeren tümcelerin Sinn sahibi olmamaları nedeniyle bir düşünceye sahip oldukları söylenemeyeceği gibi aynı şekilde bir 'Bedeutung'a sahip oldukları da söylenemez. Buna karşın Bedeutung’u olan her tümce bir Sinn’e ve düşünceye sahip olmak durumundadır. Zira Frege’ye göre tümcenin doğruluk değeri, tümcedeki düşünce tarafından belirlenmekte; bu nedenle de Bedeutung ile düşünce zorunlu olarak birbirini gerektirmektedir. Düşünce içeren her önerme, Bedeutung'a ve Bedeutung'a sahip her önerme de bir Sinn’e sahip olmasına karşın, Sinn sahibi olan her tümcenin bir düşünce içermesi veya bir doğruluğa göndermesi gerekmemektedir. ${ }^{25}$

Ayrıca Frege, düşüncelerin zihnin kurucu unsurları olmalarına karşın zihin tarafından tümce bağlamında yakalanmaları gereken mantıksal nesneler oldukları yönündeki kanaatini, dilde düşüncelerin yerini tutan anlamların, tümce bağlamındaki işlevlerinin mantıksal analiziyle pekiştirmektedir. Demek ki düşünceler, dil ve yargı bağlamında yakalanan mantıksal nesneler olarak üçüncü bir âlemde bulunmaktadır.

Düşüncelerin zihinde bulunuşu, kuşun elde olması gibi değil; kemik ve kasın elde yer alması gibidir. Nesnel olan, zihne yabancı ya da dışsal bir şey olmayıp zihnin oluşturucusu; onun olmazsa olmaz parçasıdır" demesine karşın zihnin oluşturucu bir parçası olan düşünceleri, neden zihnin dışında bir yerde (yargı bağlamında) yakalamaya çalışmaktadır? Ne öznel tasarımlar gibi zihne içkin, ne de dış dünya nesneleri gibi zihinden bağımsız olan düşünceler nerededir? Frege, işte bu soruyu, düşünceleri ne zihne mahkûm ederek tasarımlara indirgeyerek ne de dış dünya nesneleri statüsüne indirgeyerek yanıtlamak ister. Düşünceleri ne dış dünyada ne de zihinde konuşlandıran Frege, onların bu iki dünyanın dışındaki üçüncü bir âlemde (düşünceler âleminde) bulunduğunu ve onların nesne olmaklığının yalnızca mantıksal bir varoluşa sahip olduğunu savunmaktadır. İşte düşünceler, yargı bağlamında onlar yerine duran Sinn’lerin yargı bağlamındaki işlevlerinin çözümlenmesiyle yakalanmaktadır. Frege düşüncelerin tümce bağlamında yakalanmaları sürecini üç aşamalı olarak kategorize etmektedir: Düşünme, yargilama ve iddiada bulunma. ${ }^{26}$

25 Tarhan, “Husserl ve Frege'de Anlam Sorunu”, ss.165-166.

26 A.g.e., s.207. 


\section{Sonuç}

Frege'nin modern sembolik mantığın kuruluşunda büyük rol oynayan kavram yazısıyla ortaya koyduğu formel mantık dili, yargıların "fonksiyon - argüman" ayrımı üzerinden analiz edilmesini sağlamıştır. Böylece özel adların anlam ve gönderimleri arasında yapılan ayrımın bir türevi de yargıların anlam ve gönderimleri arasında yapılmış, yargıların doğruluk değeri alabilme koşulu olan düşünceler ise Frege'nin "Der Gedanke” adlı metninde tümcelerin anlamlarına indirgenmiştir. Frege'nin bu metninde düşünceyi, "tümcenin anlamı” olarak tanımlamış olmasının kendi felsefi pozisyonu açısından büyük bir çelişki doğurduğunun altını çizmek ve bu çelişkinin aşılabilmesi için Frege'nin kuramında yerli yerine oturacak bir başka düşünce tanımı önermek üzere kaleme alınmış olan bu makalede, bizim Frege’ye önerimiz, düşünceleri tümcelerin anlamları üzerinden tanımlamak yerine, tümcelerin gönderdiği fonksiyon değerlerinin bir fonksiyonu olarak düşünmek şeklindedir. Nitekim düşüncelerin, Frege’nin yaptığı gibi tümcelerin anlamları olarak görülmesi yanılgısı, sahte özel ad içeren tümcelerin de anlamlı olmaları sebebiyle bir düşünce içerdiklerini düşünmeye sevk etmektedir. Oysa bu durum, düşünce içeren tümcelerin doğruluk değeri aldığı yönündeki Fregeci bir diğer kabul ile çatışmaktadır. Nitekim Frege’ye göre sahte özel ad içeren tümceler doğruluk değerinden yoksundur. Öyleyse düşüncelerin, tümcelerin doğruluk değerlerinin taşıyıcısı olarak görülmesine karşın nasıl olup da tümce anlamına indirgendiği şüphelidir. Zira anlamlı olmasına karşın doğruluk değerinden yoksun olan ifadeler de bulunmaktadır. İşte bu çelişkiyi çözmek üzere bizim önerimiz, Frege felsefesinde düşüncelerin "tümce anlamları" olarak görülmeleri yanılgısı yerine, "fonksiyon değeri” olarak görülmeleri yönündedir. Başka bir deyişle: Düşünceler, tümcelerin 'doğrulanabilir' anlamıdır. Çünkü düşünceler, " $f_{(x)} \rightarrow y$ " gibi bir ifadede, " $x$ " değeriyle tamamlanmış olan doymuş fonksiyonun gönderdiği " $y$ ” değerine tekabül etmekte ve fonksiyonun alacağı doğruluk değeri, bu "y” değerine göre belirlenmektedir. Yani “y” değeri, fonksiyonun doğru mu yanlış mı olduğunu belirlememizi sağlayan fonksiyon değeri olarak $\mathrm{f}_{(\mathrm{x})}$ fonksiyonunun düşüncesidir.

Demek ki düşünceler, yalnızca doymuş ifadelerde bulunmakta ve ifadenin bir doğruluk değeri alabilmesini sağlamaktadır. Bu nedenle de düşünceleri ne doğrudan tümcenin anlamına, ne de doğrudan tümcenin doğruluk değerine indirgemek mümkündür. Kaldı ki zaten Frege, düşünceleri ne dış dünya nesneleri gibi doğaya, ne de iç dünya nesneleri gibi zihne mahkûm etmiştir. Bu iki düzlemin dışında, "düşünceler âlemi” adını verdiği üçüncü bir alanda (dritte Reich) bulunan düşünceler, aritmetik ve mantık alanındaki yargıların doğrulanabilir olma imkânını kurtaran mantıksal nesneler olarak düşünülmektedir. Bunlar zihnin kurucu unsurları olmakla birlikte bilinç tarafından tümce bağlamında yakalanmayı talep eden mantıksal ne'liklerdir. Frege, kesin bir bilgi üretebilmenin imkânını ortaya koyan düşünceler sayesinde doğruluk değerinden yoksun olmasına karşın anlamlı olmayı sürdürebilen ifadelerin imkânını kurtarmış ve düşünceyi, doğrulanabilir bir anlam içeriği olarak konuşlandırmıştır. Dolayısıyla biz bu anlayışla Frege’nin "düşünce" tanımı verirken "Der Gedanke" adlı metninde "Düşünceler, tümcelerin anlamlarıdır" şeklindeki beyanını bir talihsizlik olarak görmekte ve bu ifadeyle Frege'nin kast etmiş olduğu şeyin ancak "doğrulanabilir anlam" veya "fonksiyon değeri” olabileceğini öne sürmekteyiz. 
Finansal Destek: Yazar bu çalışma için finansal destek almamıştır.

\section{Kaynaklar}

Frege, Gottlob, “Ausführungen Über Sinn und Bedeutung” (1892-1895), şurada: Gottfried, Gabriel, "Schriften zur Logik und Sprachphilosophie", Felix Meiner Verlag, Hamburg, 1969, ss.25-34.

Frege, Gottlob, "Der Gedanke”, şurada: Frege, Gottlob, “Beiträge zur Philosophie des deutschen Idealismus”, 1918-1919, ss.58-77.

Frege, Gottlob, “Über Funktion und Begriff”, şurada: Frege, Gottlob, “Funktion, Begriff, Bedeutung. FünfLogische Studien”, Ed: Patzig, Günther, Kleine Vandenhoeck, 5.Bask1, 1980, Göttingen, ss.18-39.

Frege, Gottlob, “Über Sinn und Bedeutung”, şurada: Frege, Gottlob, “Funktion, Begriff, Bedeutung: Fünf logische Studien”, Patzig, Günther, ss.40-66.

Güven, Özgüç, “Kant, Bolzano ve Frege'de Yargıların Temellendirilmesi ve Apriorilik Sorunu”, İstanbul Üniversitesi Sosyal Bilimler Enstitüsü Felsefe Anabilim Dalı Doktora Tezi, İstanbul, 2012.

Tarhan, Diler Ezgi, “Husserl ve Frege'de Anlam Sorunu”, İstanbul Üniversitesi Sosyal Bilimler Enstitüsü Felsefe Anabilim Dalı Doktora Tezi, İstanbul, 2019. 
